\title{
Analisis Faktor-Faktor Yang Mempengaruhi Manajemen Laba Dengan Leverage Sebagai Variabel Moderasi
}

Studi Empiris Pada Perusahaan Manufaktur Yang Terdaftar di BEI Tahun 2013-2017

\author{
Jamaluddin Ali dan Nur Sry Nansih Cahyani \\ Sekolah Tinggi Ilmu Ekonomi Hidayatullah, Depok, Indonesia \\ Email : jamal@stiehidayatullah.ac.id
}

\begin{abstract}
In the current era of globalization, the very rapid development of business requires accuracy in making decisions, in making decisions, management must pay attention to and consider policies made to reduce the possibility of risks and uncertainties that will occur. One way this is done is by managing earnings management. Earnings management is a behavior performed by company management to increase or decrease profits in the financial reporting process. The purpose of this study is to examine and analyze the effect of tax planning, deferred tax assets, deferred tax burden, and profitability on earnings management with leverage as a moderating variable in manufacturing companies listed on the Jakarta Stock Exchange (IDX) in 2013-2017. The number of samples used in the study were 10 companies. In this study using multiple regression. The results of this study indicate that tax planning has a positive effect on earnings management, deferred tax assets have a positive effect on earnings management, deferred tax expenses have no effect on earnings management, profitability has no effect on earnings management.
\end{abstract}

Keywords: Tax Planning, Deferred Tax Assets, Deferred Tax Expenses, Profitability, Profit Management

\begin{abstract}
ABSTRAK
Dalam era globalisasi saat ini perkembangan bisnis yang sangat pesat dibutuhkan ketepatan dalam mengambil keputusan, dalam pengambilan keputusan manajemen harus memperhatikan dan mempertimbangkan kebijakan-kebijakan yang dibuat untuk mengurangi kemungkinan risiko dan ketidakpastian yang akan terjadi. Salah satu cara yang dilakukan adalah dengan mengelola manajemen laba.. Manajemen laba merupakan perilaku yang dilakukan oleh manajemen perusahaan untuk meningkatkan atau menurunkan laba dalam proses pelaporan keuangan, Tujuan penelitian ini adalah untuk menguji dan menganalisis pengaruh tax planning,asset pajak tangguhan beban pajak tangguhan, dan profitabilitas terhadap manajemen laba dengan leverage sebagai variabel moderasi pada perusahaan manufaktur yang terdaftar di Bursa Efek Jakarta (BEI) pada tahun 2013-2017. Jumlah sampel yang digunakan dalam penelitian sebanyak 10 perusahaan. Dalam penelitian ini menggunakan multiple regresi. Hasil penelitian ini menunjukkan bahwa Tax Planing berpengaruh positif tehadap manajemen laba, Aset Pajak Tangguhan berpengaruh positif terhadap Manajemen Laba, Beban Pajak Tangguhan Tidak Berpengaruh terhadap Manajemen Laba, Profitabilitas tidak berpengaruh terhadap Manajemen Laba.
\end{abstract}

Kata Kunci: Tax Planing, Aset Pajak Tangguhan, Beban Pajak Tangguhan, Profitabilitas, Manajemen Laba

JIMKES

Jurnal Ilmiah Manajemen Kesatuan Vol. 9 No. 1,2021 pp. $151-158$
IBI Kesatuan ISSN $2337-7860$ E-ISSN $2721-169 \mathrm{X}$ 
Manufacturers'

Profit Management and Leverage

\section{PENDAHULUAN}

Laporan keuangan merupakan suatu laporan akuntansi yang dipruntukkan untuk memberikan informasi-informasi keuangan kepada pihak-pihak yang berkepentingan untuk menilai kinerja dari suatu perusahaan. Secara umum kinerja keuangan sebuah perusahaan dapat dilihat dari laporan keuangan yang disajikan serta kebijakan-kebijakan yang diambil leh pihak manajemen sehingga dapat memberikan informasi yang bermafaat bagi pihak lainnya. Laporan keuangan juga menggambarkan hasil pertanggungjawaban manajemen atas penggunaan sumber daya atau asset perusahaan yang dipercayakan kepada mereka untuk dikelola, Salah satu unsur laporan keuangan yang sangat bermanfaat bagi pemegang saham adalah laporan laba rugi, dimana pengguna informasi dapat melihat secara kasat mata apakah perusahaan dalam kondisi baik atau tidak serta keberhasilan kinerja perusahaan. Dalam menjalankan bisnis atau usaha perlu ketepatan dalam pengambilan keputusan manajemen harus memperhatikan dan mempertimbangkan kebijakan-kebijakan yang dibuat untuk mengurangi kemungkinan risiko dan ketidakpastian yang akan terjadi.

Manajemen laba adalah perilaku yang dilakukan oleh manajemen perusahaan untuk meningkatkan atau menurunkan laba dalam proses pelaporan keuangan eksternal yang bertujuan untuk menguntungkan dirinya sendiri (Belkaoui, 2007:201). Manajemen laba dilakukan manajemen dengan menggunakan penilaian tertentu dalam pelaporan keuangan dan menyusun transaksi untuk mengubah laporan keuangan guna menyesatkan stakeholders mengenai kinerja ekonomi yang terjadi. Manajemen laba salah satu fenomena yang tidak asing lagi dalam dunia akuntansi. Istilah manajemen laba ini muncul karena konsekuensi langsung dari banyak upaya manajer atau penyedia laporan keuangan untuk memanipulasi informasi akuntansi khususnya laba. Manipulasi laba memiliki tujuan untuk kepentingan pribadi maupun kepentingan perusahaan karena ada motivasi atau tekanan yang muncul di sisi penyedia laporan keuangan untuk memanipulasi laporan keuangan menurut Healy dan Wahlen (1999).

Laporan keuangan sangat penting terutama pada laporan laba rugi disadari oleh manajemen sehingga manajemen cenderung melakukan disfunctional behaviour (perilaku tidak semestinya). Konflik keagenan akan muncul apabila tiap-tiap pihak, baik principal maupun agent mempunyai perbedaan kepentingan dan ingin memperjuangkan kepentingan masing-masing. Disfunctional behaviour tersebut dipengaruhi oleh adanya asimetri informasi dalam konsep teori keagenan.

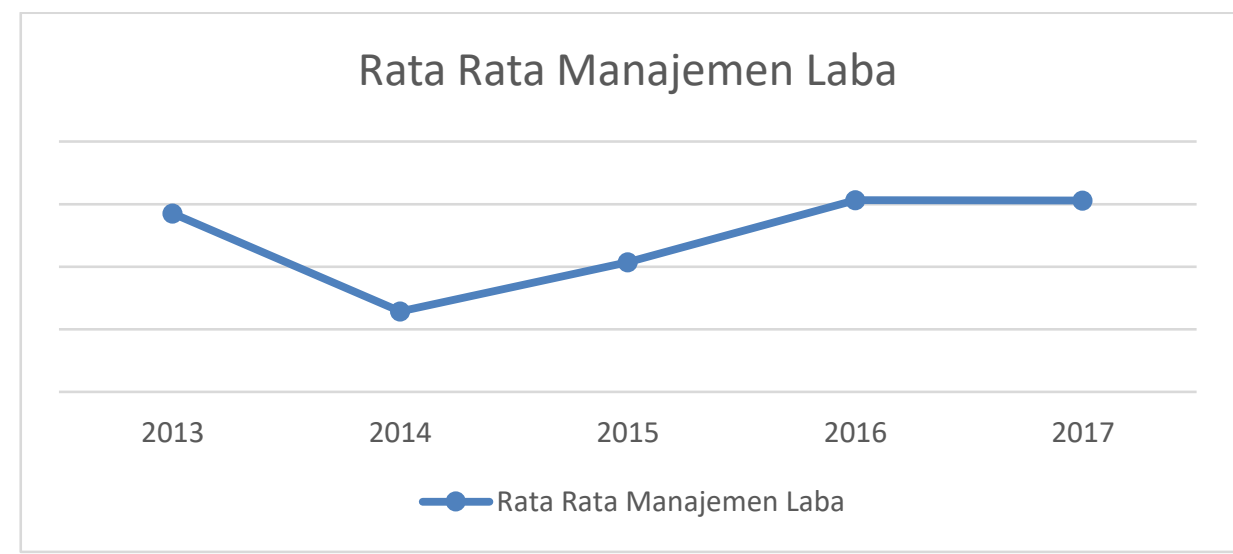

Gambar 1 Grafik Rata Rata Manajemen Laba

Beberapa penelitian menganalisa faktor-faktor yang mempengaruhi manajemen laba antara lain Santana (2016), hasil penelitian yang menunjukkan hubungan perencanaan pajak berpengaruh positif terhadap manajemen laba. Fitriany (2016), hasil penelitian hubungan perencanaan pajak berpengaruh positif terhadap manajemen laba. Berbeda dengan penelitian yang dilakukan oleh Wardani (2018), hasil penelitian menunjukkan perencanaan pajak tidak berpengaruh terhadap manajemen laba. Hubungan antara asset pajak tangguhan juga telah dilakukan oleh peneliti terdahulu diantaranya, yang 
memperoleh hasil penelitian hubungan asset pajak tangguhan berpengaruh positif terhadap manajemen laba Fitriany (2016).

Hasil penelitian hubungan asset pajak tangguhan berpengaruh positif terhadap manajemen laba Timuriana (2015). Hal ini bertolak belakang dengan penelitian yang diungkapkan oleh Zulaikha (2007), yaitu hasil penelitian hubungan asset pajak tangguhan tidak berpengaruh terhadap manajemen laba. Hasil penelitian hubungan beban pajak tangguhan berpengaruh positif terhadap manajemen laba Sumomba (2012). Sedangkan menurut peneliti Andreani (2015) didapatkan hasil hubungan antara beban pajak tangguhan tidak berpengaruh terhadap manajemen laba. Hasil penelitian leverage dan profitabilitas berpengaruh positif terhadap manajemen laba, Ayu Dwi (2017). Hasil penelitian ini sangat bertolak belakang dengan peneliti Gunawan (2015) leverage dan profitabilitas tidak berpengaruh terhadap manajemen laba.

Penelitian ini bertujuan untuk menguji dan menganalisa seberapa besar pengaruh tax planning, asset pajak tangguhan, beban pajak tangguhan, leverage, profitabilitas terhadap manajemen laba dengan kualitas audit sebagai pemoderasi. Objek penelitian ditekankan pada perusahaan manufaktur sub-sektor consumer goods tahun 2013-2017.

\section{Pengembangan Hipotesis}

Menururt Anthony dan Govindarajan (2005) teori agensi adalah hubungan atau kontrak antara principal dan agent. Asumsi menurut teory agensi adalah tiap-tiap individu semata-mata termotivasi oleh kepentingan dirinya sendiri sehingga menimbulkan konflik kepentingan antara principal dan agent. Menurut Ahmad Elqorni (2009) teori agensi menyatakan adanya hubungan kerja antara pihak yang memberi wewenang (principal) yaitu investor dengan pihak yang menerima wewenang (agency) yaitu manajer, dalam bentuk kontrak kerja sama.

Menurut Schipper (1989) dalam Rahmawati dkk (2006) menyatakan bahwa manajemen laba merupakan suatu intervensi dengan tujuan tertentu dalam proses pelaporan keuangan eksternal untuk memperoleh beberapa keuntungan privat (sebagai lawan untuk memudahkan operasi yang netral dari proses tersebut ). Tetapi lebih condong dikaitkan dengan pemilihan metode akuntansi yang secara sengaja dipilih oleh manajemen untuk tujuan tertentu dalam batasan GAAP. Perencanaan pajak (tax planning) menurut Chairil Anwar (2013) merupakann rangkaian strategi yang dilakukan manajemen untuk mengatur akuntansi dan keuangan perusahaan dengan meminimalkan kewajiban perpajakan dengan tujuan meminimalisir kewajiban pajak dengan tanpa melanggar undang-undang. Berdasarkan teori diatas, dapat disimpulkan bahwa peluang perusahaan melakukan praktek manajemen laba semakin tinggi disebabkan adanya perencanaan pajak. Hipotesis yang dapat di rumuskan adalah

\section{$\mathrm{H}_{1}$ : Perencanaan Pajak memiliki pengaruh terhadap Manajemen Laba}

Dilihat dari aspek perpajakan, pajak tangguhan adalah beban pajak (deferred tax expense) atau manfaat pajak (deferred tax income) yang dapat memberikan pengaruh menambah atau mengurangi beban pajak tahun bersangkutan. Pajak tangguhan dapat dipahami dari sudut pandang akuntansi sebagai akun aset dan liabilitas.

Mengacu pada pernyataan diatas, dapat diekspektasikan adanya peranan antara aset pajak tangguhan yang bias memungkinkan untuk digunakan sebagai indikator adanya manajemen laba. Apabila jumlah aset pajak tangguhan semakin besar maka akan semakin tinggi manajemen melakukan manajemen laba (earning management). Hipotesis dapat dirumuskan:

\section{$\mathrm{H}_{2}$ : Aset Pajak Tangguhan memiliki pengaruh terhadap Manajemen Laba. $\mathbf{H}_{3}$ : Beban Pajak Tangguhan memilki pengaruh terhadap Manajemen Laba}

Menurut Para Ahli salah satu indikator yang penting untuk menilai suatu perusahaan. digunakan untuk mengukur kemampuan perusahaan dalam menghasilkan laba juga untuk mengetahui efektifitas perusahaan adalah dengan mengukur rasio profitabilitasnya. Rasio profitabilitas mengukur keberhasilan menajemen sebagaimana ditunjukkan oleh laba yang dihasilkan oleh penjualan dan investasi. Pertumbuhan profitabilitas ini ditandai dengan perubahan profit margin on sales. Dengan tingkat profitabilitas yang tinggi berarti perusahaan akan beroperasi pada tingkat biaya rendah 
Manufacturers' Profit Management and Leverage

\section{4}

yang akhirnya akan menghasilkan laba yang tinggi. Rasio profitabilitas perusahaan yang semakin tinggi maka berarti semakin baik kinerja perusahaan tersebut, Apabila manajemen mampu mencapai target dari principal, maka manajemen dianggap mempunyai kinerja yang baik, dan profitabilitas akan mempengaruhi manajer dalam melakukan tindakan manajemen laba, (Rahmawati dkk,2008), sehingga hipotesis yang dapat dirumuskan adalah:

\section{$\mathrm{H}_{4}$ : Profitabilitas Berpengaruh Positif terhadap Manajemen Laba.}

Leverage adalah suatu tingkat kemampuan perusahaan dalam menggunakan aktiva dan/atau dana yang memiliki beban tetap (hutang dan atau saham istimewa) dalam rangka mewujudkan tujuan perusahaan untuk memaksimisasi kekayaan pemilik perusahaan. Fakhrudin (2008:109) berpendapat leverage merupakan jumlah utang yang digunakan untuk membiayai / membeli aset-aset perusahaan. Perusahaan-perusahaan yang memiliki utang lebih besar dari equity dikatakan sebagai perusahaan dengan tingkat leverage yang tinggi. Menurut Sartono (2008:257), leverage adalah penggunaan aset dan sumber dana (source of funds) oleh perusahaan yang memiliki biaya tetap (beban tetap) dengan maksud agar meningkatkan keuntungan potensial pemegang saham.

\section{METODE PENELITIAN \\ Rancangan Penelitian}

Dalam penelitian ini peneliti menggunakan metode kausal. Data yang digunakan adalah data sekunder. Populasi yang digunakan dalam penelitian ini adalah perusahaan manufaktur yang terdaftar di Bursa Efek Indonesia periode 2013-2017. Sampel dalam penelitian ini diambil dengan menggunakan metode purposive sampling. Adapun kriteria tertentu sampel pada penelitian ini adalah:

a. Perusahaan manufaktur sub-sektor makanan dan minuman yang terdaftar di BEI pada tahun 2013-2017.

b. Perusahaan manufaktur sub-sektor makanan dan minuman yang mempublikasikan laporan keuangan audit per 31 Desember 2013 sampai dengan 31 Desember 2017.

c. Mempunyai data lengkap yang terkait dengan variabel dalam penelitian ini.

Untuk mengetahui apakah data dalam penelitian ini layak atau tidak digunakan, maka terlebih dahulu dilakukan pengujian asumsi klasik yang meliputi: 1) Uji normalitas; 2) Uji Multikolinearitas; 3) Uji Heteroskedastisitas; dan 4) Uji Autokorelasi. Apabila data-data yang ada telah lolos uji asumsi klasik, selanjutnya data dapat dianalisis dengan menggunakan teknik regresi linier berganda. Dikarenakan dalam penelitian ini menggunakan lebih dari dua variable, maka peneliti menggunakan uji Analisa regresi berganda. Persamaan regresi dirumuskan sebagai berikut:

$$
Y=\alpha+\beta_{1} X_{1}+\beta_{2} X_{2}+\beta_{3} X_{3}+\beta_{4} X_{4}+e
$$

Keterangan:

$\mathrm{Y}=$ Manajemen laba; $\alpha=$ konstanta $; \beta_{1}, \beta_{2}, \beta_{3}, \beta_{4}, \beta_{5}=$ Koefisien regresi dari masingmasing variabel bebas; $X_{1}=$ Tax Planning (perencanaan pajak); $X_{2}=$ Aset Pajak Tangguhan; $\mathrm{X}_{3}=$ Beban Pajak Tangguhan; $\mathrm{X}_{4}=$ Profitabilitas; $\mathrm{e}=$ error

Parameter regresi linier berganda, dapat diukur menggunakan Uji Signifikansi Individu (Uji t), Uji Signifikansi Simultan (Uji F), dan Uji Koefisien Determinasi (R2). Berdasarkan pada rumusan masalah dan hipotesis yang akan diuji, maka variable secara ringkas variable-variabel yang diteliti menggunakan pengukuran sebagai berikut:

A. Variabel dependen dalam penelitian ini adalah manajemen laba yang diproksi dengan discretionary accrual dengan menggunakan model Jones yang dimodifikasi Dechow et.al (1995) dengan langkah sebagai berikut :

1. Total accrual sesungguhnya $\mathbf{T A i t}=\mathbf{N i t}-\mathbf{C F O i t}$

Keterangan: NIit $=$ laba bersih perusahaan i pada tahun $\mathrm{t}$

$\mathrm{CFOit}=$ arus kas perusahaan i pada tahun $\mathrm{t}$

2. Total accrual yang diestimasi dengan persamaan regresi OLS (Ordinary Least Square $):$ TAit $=\alpha 0(1 /$ Ait-1 $)+\alpha 1(\Delta$ Revit /Ait-1 $)+\alpha 2($ PPEit/ Ait-1 $)+e$ 
Keterangan:

TAit $=$ Total akrual perusahaan i pada tahun $\mathrm{t}$

At- $1=$ Total aset pada periode $t$

$\triangle \mathrm{REVt}=$ Pendapan periode $\mathrm{t}$ dikurangi dengan pendapatan periode $\mathrm{t}-1$

$\triangle \mathrm{RECt}=$ Piutang periode $\mathrm{t}$ dikurangi periode $\mathrm{t}-1$

PPEt $=$ Aktiva tetap (gross property, plant, and equipment) pada periode $t$

$\mathrm{E}=$ Error term perusahaan i pada tahun $\mathrm{t}$

Pada penelitian ini peneliti hanya menggunakan langkah pertama untuk mengukur rasio manajemen laba.

B. Variabel independent dalam penelitian ini diuji dengan menggunakan skala rasio, antara lain sebagai berikut:

Perencanaan pajak pada penelitian ini dihitung dengan rumus berikut:

TAX PLAN $=\sum$ Tahun (25\% PTI - CTE)

\section{CTE $=$ TI $\times$ STR}

\section{TA Tahun}

Keterangan $:$ TAXPLAN $=$ Perencanaan pajak PTI $=$ Pre-tax income (pendapatan sebelum kena pajak); CTE = Current portion of total tax expense (beban pajak kini); $\mathrm{TA}=$ Total asset $; \mathrm{TI}=$ Taxable income; $\mathrm{STR}=$ Tax rate

Dalam penelitian ini asset pajak tangguhan sebagai variable bebas yang diukur dengan perubahan nilai aset pajak tangguhan pada akhir periode $t$ dengan $t-1$ dibagi dengan nilai aset pajak tangguhan pada akhir periode $t$.

CAPTit $=\Delta$ Aset pajak tangguhan $t-1 /$ Aset pajak tangguhan $t$

Penghitungan tentang beban pajak tangguhan dihitung dengan menggunakan indikator membobot beban pajak tangguhan dengan total aktiva atau total asset. Hal itu dilakukan untuk pembobotan beban pajak tangguhan dengan total asset pada periode $\mathrm{t}-1$ untuk memperoleh nilai yang terhitung dengan proporsional.

DTE it $=$ Beban pajak tangguhan $t /$ Total asset $t-1$

Profitabilitas merupakan gambaran mengenai kemampuan perusahaan untuk menghasilkan laba suatu perusahaan, sehingga dapat dikatakan semakin besar penghasilan yang diperoleh perusahaan maka akan berpengaruh terhadap besarnya pajak penghasilan yang harus dibayarkan. Profitabilitas dapat diukur menggungakan rasio Return on Asset (ROA). Semakin tinggi nilai ROA menunjukkan kinerja perusahaan yang semakin bagus (Pradipta dan Supriadi, 2015).

\section{Variabel pemoderasi}

$$
R O A=\frac{\text { laba bersih setelah pajak }}{\text { total aktiva }}
$$

Leverage merupakan rasio yang mengukur seberapa jauh perusahaan menggunakan utang untuk membiayai operasional perusahaan. Menurut (Harahap,2008) rasio menggambarkan hubungan antara utang perusahaan terhadap modal maupun asset. Dalam penelitian ini untuk mengukur leverage digunakan proksi Debt to Assets Ratio (DAR).

$$
D A R=\frac{\text { total hutang }}{\text { total asset }} \times 100 \%
$$

\section{HASIL DAN PEMBAHASAN}

\section{Perencanaan Pajak Terhadap Manajemen Laba}

Perencanaan pajak (TP) terhadap manajemen laba (Y) memiliki nilai signifikan 0,001 lebih kecil dari 0,05 atau $(0,001<0,05)$. Oleh karena itu, variabel perencanaan pajak memiliki pengaruh terhadap manajemen laba.

Aset Pajak Tangguhan Terhadap Manajemen Laba

Nilai koefisien regresi varibel aset pajak tangguhan bernilai positif yaitu 0,475 . Dari koefisien aset pajak tangguhan tersebut maka dapat disimpulkan bahwa aset pajak tangguhan memiliki pengaruh terhadap manajemen.

\section{Manufacturers' \\ Profit Management and Leverage}


Manufacturers'

Profit Management and Leverage
Beban Pajak Tangguhan Terhadap Manajemen Laba

Beban pajak tangguhan memiliki nilai signifikan 0,004. Oleh karena itu, variabel beban pajak tangguhan memiliki pengaruh terhadap manajemen laba.

\section{Profitabilitas terhadap Manajemen Laba}

Berdasarkan hasil uji t pada dapat diketahui bahwa variabel dari profitabilitas yang indikatornya return on asset rmemiliki nilai 0,102 maka dapat disimpulkan bahwa profitabilitas tidak berpengaruh terhadap manajemen laba.

\section{Uji R Square}

Tabel 1 Nilai R Square

156

\begin{tabular}{ll|l|l|l} 
Model & R & R Square & Adjusted R Square & Std. Error of the Estimate
\end{tabular}

\begin{tabular}{rrrrr}
\hline 1 &, $286^{\mathrm{a}}$ &, 082 &, 049 &, 466
\end{tabular}

a. Predictors: (Constant), TP, APT, BPT, PRO, LEV

Nilai R Square pada table model summary adalah sebesar 0,082 atau $8,2 \%$, hal ini berarti manajemen laba dipengaruhi oleh faktor-faktor diatas dan profitabilitas sebagai variable moderasi hanya sebesar $8,2 \%$, dan sisanya sebesar $91,8 \%$ dipengaruhi oleh variabe lainnya.

Uji F (Uji Koefisien Regresi)

\begin{tabular}{|c|c|c|c|c|c|c|}
\hline \multicolumn{7}{|c|}{ ANOVA $^{\mathrm{a}}$} \\
\hline & Model & $\begin{array}{l}\text { Sum of } \\
\text { Squares }\end{array}$ & $\mathrm{df}$ & Mean Square & $\mathrm{F}$ & Sig. \\
\hline \multirow[t]{3}{*}{1} & Regression & 1,610 & 3 & ,537 & 2,469 &, $068^{\mathrm{b}}$ \\
\hline & Residual & 18,045 & 83 & ,217 & & \\
\hline & Total & 19,655 & 86 & & & \\
\hline
\end{tabular}

a. Dependent Variable: MANLA

b. Predictors: (Constant), TP, APT, BPT, PRO, LEV

Nilai $\mathrm{F}$ hitung dan $\mathrm{F}$ table adalah 2,469 $<3,09$ dengan tingkat signifikan sebesar 0,068 atau $>0,05$, berarti Ho diterima dimana Perencanaan Pajak dan Transparansi Perusahaan sebagai variable moderasi tidak berpengaruh terhadap Nilai Perusahaan.

\section{Coefficients $^{\mathrm{a}}$}

\begin{tabular}{|c|c|c|c|c|c|c|}
\hline & \multirow[t]{2}{*}{ Model } & \multicolumn{2}{|c|}{$\begin{array}{l}\text { Unstandardized } \\
\text { Coefficients }\end{array}$} & \multirow{2}{*}{$\begin{array}{c}\text { Standardized } \\
\text { Coefficients } \\
\text { Beta }\end{array}$} & \multirow[t]{2}{*}{$\mathrm{t}$} & \multirow[t]{2}{*}{ Sig. } \\
\hline & & $\mathrm{B}$ & Std. Error & & & \\
\hline \multirow[t]{9}{*}{1} & (Constant) & 251 & ,151 & & 1,666 &, 100 \\
\hline & $\mathrm{TP}$ & , 071 & ,029 & ,303 & 2,418 & ,018 \\
\hline & APT & ,097 & , 107 & 551 & 2,224 & ,029 \\
\hline & $\mathrm{BPT}$ & ,086 & ,086 &, 421 & 2,321 & ,021 \\
\hline & PRO & 112 & , 126 & ,326 & 2,128 & ,023 \\
\hline & TPLEV & ,215 & , 168 &, 514 & 2,237 &, 123 \\
\hline & APTLEV &,- 211 & , 131 &,- 367 & $-1,611$ & ,111 \\
\hline & BPTLEV &,- 174 &, 163 &,- 284 & $-1,451$ & ,101 \\
\hline & PROLEV &,- 228 &, 146 &,- 215 & $-1,522$ &, 103 \\
\hline
\end{tabular}

Persamaan regresi adalah :

$$
\begin{aligned}
\mathrm{Y}= & 0,251+0,071 \mathrm{TP}+0,237 \mathrm{APT}+0,156 \mathrm{BPT}+0,91 \mathrm{PRO}+215 \mathrm{TP} . \mathrm{LEV}- \\
& \text { 0,211APT.LEV-174BPT.LEV-228PROLEV }
\end{aligned}
$$

Berdasarkan tabel Coefficients diatas,

- Nilai Sig. Perencanaan Pajak sebesar 0,071 atau < 0,05 berarti berpengaruh.

Perencanaan pajak berpengaruh terhadap manajemen laba

- Nilai Sig. Aset Pajak Tangguhan sebesar 0,097 atau < 0,05 berarti berpengaruh.

Aset Pajak tangguhan berpengaruh terhadap manajemen laba

- Nilai Sig. Aset Pajak Tangguhan sebesar 0,086 atau < 0,05 berarti berpengaruh.

Beban Pajak tangguhan berpengaruh terhadap manajemen laba 
- Nilai Sig. Aset Pajak Tangguhan sebesar 0,112 atau > 0,05 berarti tidak berpengaruh. Profitabilitas tidak berpengaruh terhadap manajemen laba

- Nilai Sig. Interaksi (Interaksi semua faktor dengan leverage) menunjukkan

Leverage memoderasi pengaruh faktor faktor tersebut diatas (TP,APT,BPT, PRO) terhadap manajemen laba.

\section{PENUTUP}

Hasil penelitian ini menegaskan bahwa variabel independen (tax planning, asset pajak tangguhan, beban pajak tangguhan) mempengaruhi manajemen laba. Tetapi Profitabilitas tidak berpengaruh terhadap manajemen laba, Hasil penelitian juga menunjukkan bahwa leverage tidak mampu memoderasi hubungan tersebut. Beberapa keterbatasan yang dapat melemahkan hasil penelitian, yaitu pertama, terbatasnya referensi untuk menjelaskan varibel moderasi. Kedua tidak ditemukan penelitian sebelumnya terkait dengan leverage dalam memoderasi hubungan antara varibel independent dengan variable dependen. Sehingga hasil yang diperoleh kurang mendapat dukungan dan kurang kuat dalam menjelaskan fenomena yang ada.

\section{DAFTAR PUSTAKA}

[1] Dewi, P. E. P., \& Wirawati, N. G. P. (2019). Pengaruh Leverage Terhadap Manajemen Laba Dengan Corporate Governance Sebagai Variabel Pemoderasi. EJurnal Akuntansi, 505. https://doi.org/10.24843/eja.2019.v27.i01.p19

[2] V. O. L. N. O. A., Dan, S., Implementasi, S., \& Tax, P. (2019). Jimea-Jurnal Inovasi Manajemen Ekonomi Dan Akuntasi Jimea-Jurnal Inovasi Manajemen Ekonomi Dan Akuntasi. 1(1), 1-25.

[3] Gunawan, K., Darmawan, A. S., \& Purnamawati, I. G. A. (2015). Leverage Terhadap Manajemen Laba Pada Perusahaan Manufaktur Yang Terdaftar Di Bursa Efek Indonesia ( Bei ). E-Journal S1 Ak Universitas Pendidikan Ganesha Jurusan Akuntansi Program S1, 03(01), 1-8.

[4] Hangga, R., Kumala, D., Sunarta, K., Fadillah, H., Studi, P., Fakultas, A., \& Universitas, E. (2019). MANUFAKTUR SUB SEKTOR MAKANAN DANMINUMAN YANG TERDAFTAR DI BURSA EFEK INDONESIA PERIODE 2013-2017 1) Mahasiswa Fakultas Ekonomi Universitas Pakuan.

[5] Hasty, A. D., Herawaty, V., \& Trisakti, U. (2017). PENGARUH STRUKTUR KEPEMILIKAN, LEVERAGE, PROFITABILITAS DAN KEBIJAKAN DIVIDEN TERHADAP MANAJEMEN LABA DENGAN KUALITAS AUDIT SEBAGAI VARIABEL MODERASI. 17(1), 1-16.

[6] Hudiani, N., \& Herawaty, V. (2019). Pengaruh Kualitas Audit Dan Kompetensi Komite Audit Terhadap Manajemen Laba Dengan Manipulasi Laba Sebagai Variabel Moderasi. Jurnal Magister Akuntansi Trisakti, 4(2), 181. https://doi.org/10.25105/jmat.v4i2.5065

[7] Institusional, K., Audit, K., \& Dharma, U. B. (2018). (Pendekatan Pada Perusahaan Manufaktur Yang Terdaftar Di BEI. 3, 1-10.

[8] Oliver, J. (2013). PENGARUH ASET PAJAK TANGGUHAN, BEBAN PAJAK TANGGUHAN DAN PERENCANAAN PAJAK TERHADAP MANAJEMEN LABA. Journal of Chemical Information and Modeling, 53(9), 1689-1699. https://doi.org/10.1017/CBO9781107415324.004

[9] Profitabilitas, D. A. N., Manajemen, T., \& Pada, L. (2019). PERUSAHAAN MANUFAKTUR YANG TERDAFTAR DI BURSA EFEK INDONESIA PERIODE 2012 - 2017 1) Mahasiswa Fakultas Ekonomi Universitas Pakuan 2) Dosen Fakultas Ekonomi Universitas Pakuan 3 ) Dosen Fakultas Ekonomi Universitas Pakuan.

[10] Santi, D. K., \& Wardani, D. K. (2018). Pengaruh Tax Planning, Ukuran Perusahaan, Corporate Social Responsibility (Csr) Terhadap Manajemen Laba. Jurnal Akuntansi, 
Manufacturers'

Profit Management and Leverage
6(1), 11-24. https://doi.org/10.24964/ja.v6i1.536

[11] Suyoto, H., Dwimulyani, S., Trisakti, U., Data, U. K., Data, U. N., Setelah, R., Outlier, U., \& Laba, M. (2019). Pengaruh Leverage Dan Perencanaan Pajak Terhadap. $1-9$.

[12] Timuriana, T., \& Muhamad, R. R. (2015). Pengaruh Aset Pajak Tangguhan Dan Beban Pajak Tangguhan Terhadap Manajemen Laba. JIAFE (Jurnal Ilmiah Akuntansi Fakultas Ekonomi), 1(2), 12-20. https://doi.org/10.34204/jiafe.v1i2.512

[13] Ukuran, D. A. N., \& Terhadap, P. (2016). Fakultas Ekonomi dan Bisnis Universitas Udayana (Unud), Bali, Indonesia PENDAHULUAN Laporan keuangan merupakan salah satu alat penting sebagai bahan pertimbangan pengambilan keputusan dalam ekonomi perusahaan. Laporan keuangan memuat segala informasi . 3, 1555-1583. 